\title{
Polymer electrolytes for electrochromic devices through solvent casting and sol-
}

\section{gel routes}

Rita Leones $^{1,2}$, Rodrigo C. Sabadini ${ }^{3}$, Franciani C. Sentanin ${ }^{3}$, José M. S. S. Esperança ${ }^{2,4}$, Agnieszka Pawlicka $^{3}$ and Maria Manuela Silva ${ }^{1, *}$

${ }^{1}$ Centro de Química, Universidade do Minho, Gualtar, 4710-057 Braga, Portugal

${ }^{2}$ Instituto de Tecnologia Química e Biológica António Xavier, Universidade Nova de Lisboa, 2780 157 Oeiras, Portugal

${ }^{3}$ Instituto de Química de São Carlos, Universidade de São Paulo, 13566-590 São Carlos, SP-Brasil ${ }^{4}$ LAQV, REQUIMTE, Departamento de Química, Faculdade de Ciências e Tecnologia, Universidade Nova de Lisboa, 2829-516 Caparica, Portugal

Corresponding author *: nini@quimica.uminho.pt

$+351253604058$ 


\begin{abstract}
Ionically conductive membranes of gelatin and d-PCL(530)/siloxane doped with cyano-based ionic liquids (ILs) were prepared through solvent casting and sol-gel methods, respectively. The membranes were characterized in terms of ionic conductivity, thermal behavior, morphology, and structure. All samples, except the d-PCL(530)/siloxane matrix, exhibited a predominantly amorphous morphology. The samples prepared through solvent casting and sol-gel displayed a minimum thermal stability of 170 and $230{ }^{\circ} \mathrm{C}$, respectively. The ionic conductivity varied accordingly with the type, quantity, and length of the alkyl chain of the cation of the ILs. The sample with the highest ionic conductivity was gelatin ${ }_{0.5}\left[\mathrm{C}_{2} \mathrm{mim}\right]\left[\mathrm{N}(\mathrm{CN})_{2}\right]$ with $2.40 \times 10^{-3} \mathrm{~S}^{\cdot} \mathrm{cm}^{-1}$ at $25{ }^{\circ} \mathrm{C}$ and $1.68 \times 10^{-2} \mathrm{Scm}^{-1}$ at $95{ }^{\circ} \mathrm{C}$. The good results of ionic conductivity encouraged the assembly and characterization of prototypes of electrochromic devices (ECDs). The best results were obtained with glass/ITO/ $/ \mathrm{WO}_{3} /$ gelatin ${ }_{1}\left[\mathrm{C}_{2} \mathrm{mim}\right][\mathrm{SCN}] / \mathrm{CeO}_{2}-\mathrm{TiO}_{2} / \mathrm{ITO} /$ glass configuration that showed a fast color switching time $(\sim 15 \mathrm{~s})$ and a good open circuit memory ( $\sim 4$ hours $)$. The ECD changed its color from pale blue to transparent, and its charge density decreased from -17.53 to $2.71 \mathrm{mC}^{\mathrm{cm}} \mathrm{cm}^{-2}$ during 640 color/bleaching cycles.
\end{abstract}

Keywords: sol-gel, solvent casting, cyano-based ionic liquids, solid polymer electrolyte, electrochromic device. 


\section{Introduction}

Electrochromism is the capability of a material to reversibly alter its optical properties due to a redox reaction. This color alternation is induced by application of low current potentials [1]. Electrochromic windows, anti-glare mirrors, helmet visors, goggles, electrochromic displays, and sensors are examples of electrochromic devices (ECDs) envisaged applications [2, 3]. Some of these have already reached commercialization, e.g., NTERA is manufacturing iPod EC displays, while Gentex and Donnelly are fabricating auto dimming rear mirrors [4-6].

High performance ECDs should depict high electrochromic efficiency, short response time, good stability, high optical contrast, and good optical memory [1]. Typically, an ECD is composed of a glass substrate (GS), a transparent conducting oxide (TCO), an electrochromic coating (EC), an ion conductor (IC), and an ion storage coating, also referred as counter electrode (CE). Often TCO is indium tin oxide (ITO) and EC is tungsten oxide $\left(\mathrm{WO}_{3}\right)$ [3]. The IC is an electrolyte and it can be either liquid, gel, or solid. Its function is to avoid electronic charge flow but allow mutual ion exchange $[7,8]$. Though the electrolyte can be either liquid, gel, or solid, but the solid-state design is the preferred one for ECDs. Liquid electrolytes are associated with leakage risks, high flammability, low stability, and show problems on the large scale [1,9]. On the other side, polymer electrolytes (PEs) can act as a separator and a binder; exhibit reduced reactivity; operate in a wider temperature range; have better mechanical strength and enhanced protection and stability; and their easy processing allows to fine-tune PEs membranes thickness and area [1].

The current research demand for biodegradable, low cost, and highly efficient materials drew attentions to biopolymers. In this work we synthesized and characterized solid polymer electrolytes (SPEs) based on gelatin or poly( $\varepsilon$-caprolactone) (PCL(530), where 530 is the average molecular weight of the polymer in $\mathrm{g}^{\cdot \mathrm{mol}^{-1}}$ ). Gelatin is a protein produced by partial hydrolysis of collagen, which can be found in animal skin, bone, and connective tissue. Gelatin amino acid composition is characterized by a repeating sequence of Glycine-X-Y triplet, where $\mathrm{X}$ and $\mathrm{Y}$ are frequently proline and hydroxyproline, respectively $[10,11]$. PCL(530) is a linear, aliphatic 
thermoplastic, biocompatible, permeable, hydrophobic, non-toxic for living organisms, and biodegradable poly(ester), [3]. Gelatin-based SPEs were prepared through solvent casting method, while d-PCL(530)/siloxane ormolytes (organically modified silicate electrolytes) were obtained through sol-gel. The sol-gel method is a synthetic chemical process that provides a facile and versatile route for the preparation of highly pure materials.

In order to improve ECD stability and reduce switching time, ionic liquids (ILs) were included in the SPEs composition. Additionally, the aim was that SPE simultaneously fulfills the requirements of ionic conductivity above $10^{-4} \mathrm{Scm}^{-1}$, electrochemical windows above $1.0 \mathrm{~V}$, low volatility, and environmental stability [12].

Many ILs present characteristics that make them very interesting from an industrial point of view, namely almost null volatility at room temperature [13], nonflammability [14], and high thermal stability [15]. The interchangeability between thousands of possible cations and anions can be used to tune the properties of ILs [16]. Most common ILs are composed of an organic cation and an inorganic or organic anion [17]. Pure 1-alkyl-3-methylimidazolium ILs with cyano-based anions $\left([\mathrm{SCN}]^{-},\left[\mathrm{N}(\mathrm{CN})_{2}\right]^{-}\right.$or $\left.\left[\mathrm{C}(\mathrm{CN})_{3}\right]^{-}\right)$, display, at $25^{\circ} \mathrm{C}$, very high ionic conductivities around $2.0 \times 10^{-2}$ $\mathrm{Scm}^{-1}$ and electrochemical windows of about $3.0 \mathrm{~V}$ [18-21].

The gelatin- and d-PCL(530)/siloxane-based SPEs studied here were doped with four cyanobased ILs: 1-ethyl-3-methylimidazolium thiocyanate $\quad\left(\left[\mathrm{C}_{2} \mathrm{mim}\right][\mathrm{SCN}]\right)$, 1-ethyl-3methylimidazolium dicyanamide $\quad\left(\left[\mathrm{C}_{2} \mathrm{mim}\right]\left[\mathrm{N}(\mathrm{CN})_{2}\right]\right), \quad$ 1-ethyl-3-methylimidazolium tricyanomethanide $\left(\left[\mathrm{C}_{2} \mathrm{mim}\right]\left[\mathrm{C}(\mathrm{CN})_{3}\right]\right)$, and 1-butyl-3-methylimidazolium thiocyanate $\left(\left[\mathrm{C}_{4} \mathrm{mim}\right][\mathrm{SCN}]\right)$. In this work we report the ionic conductivity, thermal behavior, structure, and morphology of gelatin- and d-PCL(530)/siloxane-ILs-SPEs. Finally, the samples were tested in small electrochromic windows and the best results were obtained with glass $/ \mathrm{ITO} / \mathrm{WO}_{3} /$ gelatin $1\left[\mathrm{C}_{2} \mathrm{mim}\right][\mathrm{SCN}] / \mathrm{CeO}_{2}-\mathrm{TiO}_{2} / \mathrm{ITO} /$ glass configuration, which was characterized by electrochemical and spectroscopic methods. 


\section{Material and methods}

\subsection{Materials}

Commercial colourless gelatin (Vahine $\left.{ }^{\circledR}\right)$, glycerol (Himedia, $99.5 \%$ ), $\alpha, \omega$-hidroxylpoly $(\varepsilon-$ caprolactone) (PCL (530) (Aldrich, average molecular weight $530 \mathrm{~g}^{-\mathrm{mol}^{-1}}$ ), and 3isocyanatepropyltriethoxysilane (ICPTES, Aldrich, 95\%) were used as received. Tetrahydrofuran (THF, Aldrich) and ethanol $\left(\mathrm{CH}_{3} \mathrm{CH}_{2} \mathrm{OH}\right.$, Riedel de Haën) were stored over molecular sieves. MilliQ water was used in all experiments.

$\left[\mathrm{C}_{2} \mathrm{mim}\right]\left[\mathrm{C}(\mathrm{CN})_{3}\right],\left[\mathrm{C}_{2} \mathrm{mim}\right]\left[\mathrm{N}(\mathrm{CN})_{2}\right],\left[\mathrm{C}_{2} \mathrm{mim}\right][\mathrm{SCN}]$, and $\left[\mathrm{C}_{4} \mathrm{mim}\right][\mathrm{SCN}]$ were acquired from IoliTec with a stated purity higher than $98 \%$. All ILs were dried under vacuum and moderate temperature for at least $48 \mathrm{~h} .{ }^{1} \mathrm{H}$ NMR and ${ }^{13} \mathrm{C}$ NMR were performed for all samples and confirmed the supplier indication.

\subsection{Solvent casting}

Commercial colourless gelatin $(1.0 \mathrm{~g})$ was dispersed in water $(15 \mathrm{~mL})$ and stirred for a few minutes at $50{ }^{\circ} \mathrm{C}$ for complete dissolution. The IL $(0.25-2.0 \mathrm{~g})$ and glycerol $(0.625 \mathrm{~g})$, as plasticizer, were added to this solution. The solution was poured on a Petri dish and left to dry for 8 h at $25^{\circ} \mathrm{C}$, then overnight at $40^{\circ} \mathrm{C}$, followed by $4 \mathrm{~h}$ at $60{ }^{\circ} \mathrm{C}$ and then cooled down to $25^{\circ} \mathrm{C}$. The resulting transparent flexible membranes showed an average thickness of $0.296 \pm 0.001 \mathrm{~mm}$. The notation gelatin $[\mathrm{IL}]$, where $\mathrm{x}$ corresponds to the quotient between the mass of the polymer and the mass of the IL, was used.

\subsection{Sol-gel}

The d-PCL(530)/siloxane-based hybrid electrolytes were prepared through a procedure described in detail elsewhere [22]. In the first step a urethane cross-link was formed between the hydroxyl (-OH) end groups of PCL(530) $(0.80 \mathrm{~g}, 1.51 \mathrm{mmol})$ and the isocyanate $(-\mathrm{N}=\mathrm{C}=\mathrm{O})$ groups of ICPTES ( $745 \mu \mathrm{L}, 3.01 \mathrm{mmol})$, in THF at $70-80{ }^{\circ} \mathrm{C}$, to yield the non-hydrolysed hybrid precursor. 
In the second step, ethanol $(705 \mu \mathrm{L}, 12.07 \mathrm{mmol})$ and water $(82 \mu \mathrm{L}, 4.55 \mathrm{mmol})$ were added to this solution to promote the characteristic sol-gel reactions of hydrolysis and condensation. $\left[\mathrm{C}_{2} \mathrm{mim}\right][\mathrm{SCN}](0.019-0.946 \mathrm{~g}, 0.11-5.59 \mathrm{mmol})$ was then incorporated in different quantities. The ormolyte sample, produced as a xerogel film, was aged for 1 month in an oven at $50{ }^{\circ} \mathrm{C}$, followed by a final drying under vacuum at $90{ }^{\circ} \mathrm{C}$ for 3 days. The membranes thickness varied between 0.447 and $0.565 \pm 0.001 \mathrm{~mm}$. These materials were identified by the notation $\mathrm{d}$ $\operatorname{PCL}(530) /$ siloxane $_{\mathrm{n}}\left[\mathrm{C}_{2} \mathrm{mim}\right][\mathrm{SCN}]$, where $\mathrm{n}$ corresponds to the number of $\left.\mathrm{C}(=\mathrm{O})\left(\mathrm{CH}_{2}\right)_{5}=\mathrm{O}\right)$ PCL repeat units per $\left[\mathrm{C}_{2} \mathrm{mim}\right]^{+}$ion.

\subsection{SPEs characterization}

Ionic conductivity: The bulk ionic conductivity was obtained using the complex plane impedance technique (Autolab PGSTAT-12; Eco Chemie) over a frequency range of $65 \mathrm{kHz}$ to 500 $\mathrm{mHz}$ and a temperature range from room temperature $\left(\sim 20^{\circ} \mathrm{C}\right)$ to $100^{\circ} \mathrm{C}$. The samples were sandwiched between two gold electrodes $(10 \mathrm{~mm}$ diameter ion-blocking gold electrode, Goodfellow, $>99.95 \%$ ) with gold electrode/polymer electrolyte/gold electrode configuration, secured in a suitable constant volume support under an argon atmosphere.

Thermal analysis: Differential scanning calorimetry (DSC) measurements were carried out using a Mettler DSC 821e. $40 \mu \mathrm{L}$ aluminum cans with perforated lids were sealed with each sample inside a glove box filled with dry argon. Gelatin-based SPEs were analyzed in the temperature range from -60 to $200{ }^{\circ} \mathrm{C}$, at a heating rate of $5{ }^{\circ} \mathrm{C} \cdot \mathrm{min}^{-1}$. d-PCL(530)/siloxane-based SPEs were analyzed from -60 to $15{ }^{\circ} \mathrm{C}$, at a heating rate of $10{ }^{\circ} \mathrm{C} \cdot \mathrm{min}^{-1}$, and from 25 to $350{ }^{\circ} \mathrm{C}$, at a heating rate of $5{ }^{\circ} \mathrm{C} \cdot \mathrm{min}^{-1}$. All measurements were carried out under a $30 \mathrm{~mL} \cdot \mathrm{min}^{-1}$ flowing argon atmosphere.

Thermogravimetric analysis (TGA) were performed with a Shimadzu TGA-50 equipment between 30 and $900{ }^{\circ} \mathrm{C}$, at a heating rate of $10{ }^{\circ} \mathrm{C} \cdot \mathrm{min}^{-1}$, and under a nitrogen atmosphere with a 60 $\mathrm{mL} \cdot \mathrm{min}^{-1}$ rate flow. Before each analysis and aiming to eliminate the traces of absorbed moisture all 
samples were subject to a first run from 30 to $105^{\circ} \mathrm{C}$, at a heating rate of $20^{\circ} \mathrm{C} \cdot \mathrm{min}^{-1}$, followed by a second isothermal run at $105^{\circ} \mathrm{C}$ during 10 minutes.

Structural and morphological measurements: X-ray diffraction (XRD) measurements were carried out at room temperature with an X-ray Rigaku Utma 4 diffractometer, power of $50 \mathrm{kV} / 50$

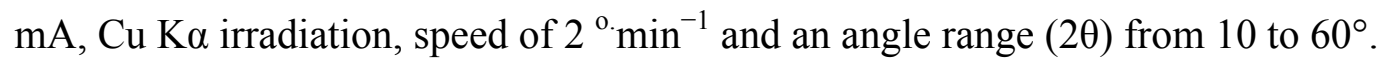

Scanning electron microscopy (SEM) images were obtained at $10 \mathrm{kV}$ with a LEO $440 \mathrm{mi}-$ croscope. Energy-dispersive X-ray spectroscopy (EDS) of the d-PCL(530)/siloxane ${ }_{n}\left[\mathrm{C}_{2} \mathrm{mim}\right][\mathrm{SCN}]$ ormolytes were performed with an EDX Link Analytical with a resolution of $133 \mathrm{eV}$.

Atomic Force Microscopy (AFM) images were taken with a Bruker AFM System (Dimension icon with scan Asyst). In all AFM analyses the intermittent-contact mode was employed by using silicon AFM probes with a force constant of $48 \mathrm{Nm}^{-1}$ and a resonance frequency of $190 \mathrm{kHz}$.

\subsection{ECD prototype}

ECD construction: $\mathrm{CeO}_{2}-\mathrm{TiO}_{2}$ and $\mathrm{WO}_{3}$ films were deposited by dip-coating on conducting ITO glass substrates (Delta Technologies, sheet resistance of $8 \mathrm{ohm}^{\mathrm{sq}} \mathrm{s}^{-1}$ ), previously cleaned and rinsed with bidistilled water and ethanol, and then dried at room temperature. The ITO substrates were withdrawn from the $\mathrm{CeO}_{2}-\mathrm{TiO}_{2}$ and $\mathrm{WO}_{3}$ solutions in a dry box (relative humidity $<40 \%$ ) at a speed of 20 and $6 \mathrm{~cm}^{-1} \mathrm{~min}^{-1}$, respectively. Finally, $\mathrm{CeO}_{2}-\mathrm{TiO}_{2}$ and $\mathrm{WO}_{3}$ coated substrates were densified in air at $450{ }^{\circ} \mathrm{C}$ for $15 \mathrm{~min}$ and at $120^{\circ} \mathrm{C}$ for $1 \mathrm{~h}$, respectively. The thin crack-free $\mathrm{CeO}_{2}-\mathrm{TiO}_{2}$ and $\mathrm{WO}_{3}$ films presented excellent optical quality and thicknesses ranging from 100 to $140 \mathrm{~nm}$. Determination of the film thickness was important because of its impact on the colouring voltage of $\mathrm{WO}_{3}[23]$.

The glass/ITO/ $\mathrm{WO}_{3} /$ gelatin $1\left[\mathrm{C}_{2} \mathrm{mim}\right][\mathrm{SCN}] / \mathrm{CeO}_{2}-\mathrm{TiO}_{2} / \mathrm{ITO} /$ glass $\mathrm{ECD}$ was assembled by placing the electrolyte between two coated glasses, i.e., glass/ITO/ $/ \mathrm{WO}_{3}$ and glass $/ \mathrm{ITO} / \mathrm{CeO}_{2}-\mathrm{TiO}_{2}$ substrates. The electrolyte film was placed with a tweezer on glass/ITO/ $/ \mathrm{WO}_{3}$ substrate, leaving 1 $\mathrm{cm}$ of free space for the electrical contact. Then, the other coated substrate (glass/ITO/CeO $-\mathrm{TiO}_{2}$ ) 
was pressed onto the film in such a way that the two coatings faced each other inside the assembled window. A $1 \mathrm{~cm}$ wide $\mathrm{Cu}$-conducting tape $\left(3 \mathrm{M}^{\circledR}\right)$ was then glued to the free edge of each substrate for electrical connection. Finally, the mounted cells were sealed with a protective tape $\left(3 \mathrm{M}^{\circledR}\right)$. The ECD had dimensions of about $1 \mathrm{~cm} \times 2 \mathrm{~cm}$ (Figure 1).

ECD characterization: The electrochemical measurements of the ECD were performed with an Autolab 302N apparatus. The cyclic voltammograms were registered over the -2.8 and $+3.0 \mathrm{~V}$ potential range at different scan rates of $50,200,300$, and $500 \mathrm{mV} \cdot \mathrm{s}^{-1}$. The chronoamperometric (CA) measurements were performed using a square wave of -2.8 and $+3.0 \mathrm{~V}$ for $15 \mathrm{~s}$. It means that one CA cycle comprised the application of $-2.8 \mathrm{~V}$ for $15 \mathrm{~s}$ and $+3.0 \mathrm{~V}$ for the next $15 \mathrm{~s}$.

The UV-Vis spectroscopy measurements of the ECD were recorded with an Agilent 8453 between 200 and $1100 \mathrm{~nm}$ after the application of -2.8 and $+3.0 \mathrm{~V}$ for $15 \mathrm{~s}$ each potential. For the memory test the UV/VIS spectra were registered as a function of time.

\section{Results and discussion}

\subsection{Ionic conductivity}

Figure 2 depicts the temperature dependence of the ionic conductivities of (a) gelatin and $\left[\mathrm{C}_{2} \mathrm{mim}\right]\left[\mathrm{C}(\mathrm{CN})_{3}\right]$, (b) gelatin and $\left[\mathrm{C}_{2} \mathrm{mim}\right]\left[\mathrm{N}(\mathrm{CN})_{2}\right]$, (c) gelatin and $\left[\mathrm{C}_{2} \mathrm{mim}\right][\mathrm{SCN}]$ or $\left[\mathrm{C}_{4} \mathrm{mim}\right][\mathrm{SCN}]$, and (d) d-PCL(530)/siloxane and $\left[\mathrm{C}_{2} \mathrm{mim}\right][\mathrm{SCN}]$ based SPEs. The conductivity plots demonstrate a remarkable enhancement, up to $10^{-3} \mathrm{~S} \mathrm{~cm}^{-1}$, of the ionic conductivities of the samples doped with IL, comparatively to the matrix samples. Depending on the quantity of IL added to the gelatin-based samples, the conductivities increased from approximately $10^{-8} \mathrm{~S} \mathrm{~cm}^{-1}$ to about $10^{-4}, 10^{-3}, 10^{-5}$, and $10^{-5} \mathrm{Scm}^{-1}$ for gelatin ${ }_{\mathrm{x}}\left[\mathrm{C}_{2} \operatorname{mim}\right]\left[\mathrm{C}(\mathrm{CN})_{3}\right]$, gelatin ${ }_{\mathrm{x}}\left[\mathrm{C}_{2} \operatorname{mim}\right]\left[\mathrm{N}(\mathrm{CN})_{2}\right]$, gelatin $_{x}\left[\mathrm{C}_{2} \operatorname{mim}\right][\mathrm{SCN}]$, and gelatin ${ }_{\mathrm{x}}\left[\mathrm{C}_{4} \mathrm{mim}\right][\mathrm{SCN}]$, respectively (Fig. 2a, b, and c). In the case of samples based on PCL it was observed an increase from about $10^{-12} \mathrm{Scm}^{-1}$ to $10^{-5} \mathrm{Scm}^{-1}$, at room temperature (Fig. 2d). Therefore, the very high ionic conductivity exhibited by the materials studied 
in this work confirms the success of the addition of ILs to the matrices. All the samples exhibited a non-linear variation of the conductivity with the temperature, which is typical of polymer electrolytes with predominantly amorphous morphology. The highest conductivity of the gelatinbased system at room temperature $\left(\mathrm{T}=25^{\circ} \mathrm{C}\right)$ is $2.40 \times 10^{-3} \mathrm{Scm}^{-1}$ for gelatin $0.5\left[\mathrm{C}_{2} \mathrm{mim}\right]\left[\mathrm{N}(\mathrm{CN})_{2}\right]$. At $95{ }^{\circ} \mathrm{C}$, it exhibits a conductivity of $1.68 \times 10^{-2} \mathrm{Scm}^{-1}$. On the opposite side, the gelatin matrix exhibited the lowest conductivity of the gelatin-based system $\left(4.94 \times 10^{-7}\right.$ and $1.27 \times 10^{-4} \mathrm{Scm}^{-1}$, at 25 and $95{ }^{\circ} \mathrm{C}$, respectively). As the temperature increases, the inter-chain hopping and intra-chain ion movements are favored, resulting in an increase of the ionic conductivity of the SPE. Also, the viscosity of ILs decreases rapidly with increasing temperature. Lower viscosities are associated with higher ion mobility, which results in higher ionic conductivity. Besides temperature, the guest salt (quantity and type) strongly influences the SPE ionic conductivity. As expected, the increase of the quantity of added IL induced an increase of the ionic conductivity (Figures 2 and 3), due to the increase of the number of charge carriers [24]. Moreover, ionic conductivity is also influenced by the length of the alkyl chain of the cation. Figure $2 \mathrm{c}$ shows that the ionic conductivity of the gelatin membranes doped with $\left[\mathrm{C}_{2} \mathrm{mim}\right][\mathrm{SCN}]$ is higher than the ionic conductivity of the ones doped with $\left[\mathrm{C}_{4} \mathrm{mim}\right][\mathrm{SCN}]$. Shorter alkyl chains generally produce ILs with lower viscosities, which facilitate ion mobility. These results are also in accordance with the ones previously assessed for SPEs based on chitosan and other ILs [25].

The most conductive membrane synthesized using the sol-gel route (d$\operatorname{PCL}(530) /$ siloxane $\left._{1}\left[\mathrm{C}_{2} \mathrm{mim}\right][\mathrm{SCN}]\right)$ still shows quite high ionic conductivities of $3.38 \times 10^{-5}$ and $8.97 \times 10^{-4} \mathrm{Scm}^{-1}$, at 25 and $95{ }^{\circ} \mathrm{C}$, respectively. Moreover, these values are at least one order of magnitude higher than the ones found for the most conductive d-PCL(530)/siloxane membrane doped with $\mathrm{LiCF}_{3} \mathrm{SO}_{3}$ [22] and $\mathrm{LiClO}_{4}$ [26], and they are similar to the ones found for d$\operatorname{PCL}(530) /$ siloxane doped with $\left[\mathrm{C}_{2} \mathrm{mim}\right]\left[\mathrm{BF}_{4}\right][3]$. The ionic conductivity values of the gelatin-ILs SPEs studied here are one order of magnitude higher than those found previously for similar samples based on gelatin [27], DNA [28, 29], agar [30], chitosan [25], and synthetic polymers 
incorporating cyano-based ILs $[19,31,32]$. The conductivities of present samples are two orders higher than the values found for gelatin doped with lithium salts [2, 33, 34].

These high ionic conductivities can be explained by the small size and well delocalized charge of the cyano-based ILs anions. The delocalization of the charge produces weak ion-ion interactions, leading to higher ionic conductivity $[35,36]$. For the gelatin-SPEs series, the order of conductivity values was $\operatorname{gelatin}_{\mathrm{x}}\left[\mathrm{C}_{2} \operatorname{mim}\right]\left[\mathrm{N}(\mathrm{CN})_{2}\right]>\operatorname{gelatin}_{\mathrm{x}}\left[\mathrm{C}_{2} \mathrm{mim}\right][\mathrm{SCN}]>$ gelatin $_{x}\left[\mathrm{C}_{2} \operatorname{mim}\right]\left[\mathrm{C}(\mathrm{CN})_{3}\right]>$ gelatin $_{\mathrm{x}}\left[\mathrm{C}_{4} \mathrm{mim}\right][\mathrm{SCN}]$. The same order is found in literature for the ILs: $\left[\mathrm{C}_{2} \operatorname{mim}\right]\left[\mathrm{N}(\mathrm{CN})_{2}\right]\left(\begin{array}{llllllllll}2.20 & \mathrm{x} & 10^{-2} & \mathrm{~S} & \mathrm{~cm}^{-1}\end{array}\right)>\left[\begin{array}{l}\mathrm{C}_{2} \mathrm{mim}\end{array}\right][\mathrm{SCN}]\left(\begin{array}{ccccc}2.01 & \mathrm{x} & 10^{-2} & \mathrm{~S} & \mathrm{~cm}^{-1}\end{array}\right)>$ $\left[\mathrm{C}_{2} \mathrm{mim}\right]\left[\mathrm{C}(\mathrm{CN})_{3}\right]\left(2.00 \times 10^{-2} \mathrm{~S} \mathrm{~cm}^{-1}\right)>\left[\mathrm{C}_{4} \mathrm{mim}\right][\mathrm{SCN}]\left(4.56 \times 10^{-3} \mathrm{~S} \mathrm{~cm}^{-1}\right)[18-20,37]$

\subsection{Thermal behavior}

The DSC thermograms (Figure 4) confirm that all the produced SPEs are predominantly amorphous, except the d-PCL(530)/siloxane matrix, which shows a semi-crystalline morphology with a $\mathrm{T}_{\mathrm{g}}$ around $-36{ }^{\circ} \mathrm{C}$. The amorphous nature of these materials is a desirable property as the absence of crystallinity is associated with optical, mechanical, and electrochemical improvements [38]. The endothermic peaks observed above $180{ }^{\circ} \mathrm{C}$, for the gelatin ${ }_{\mathrm{x}}\left[\mathrm{C}_{2} \mathrm{mim}\right]\left[\mathrm{N}(\mathrm{CN})_{2}\right] \operatorname{samples}$ with $\mathrm{x}=0.5$ and $\mathrm{x}=2$, are associated with the matrix thermal degradation.

The samples thermal stability was thoroughly evaluated by TGA. The TGA curves shown in figure 5 are consistent with a $\mathrm{T}_{\text {onset }}$ of $170{ }^{\circ} \mathrm{C}$ for the gelatin ${ }_{\mathrm{x}}[\mathrm{IL}]$ electrolytes and $230{ }^{\circ} \mathrm{C}$ for the $\mathrm{d}$ $\operatorname{PCL}(530) /$ siloxane $_{n}\left[\mathrm{C}_{2} \mathrm{mim}\right][\mathrm{SCN}]$ ormolytes.

The onset of thermal degradation of the gelatin ${ }_{x}[\mathrm{IL}]$ samples is similar to that of the gelatin matrix and is almost IL independent at about 170 to $190^{\circ} \mathrm{C}$. Only the membranes doped with the highest quantities of $\left[\mathrm{C}_{2} \mathrm{mim}\right]\left[\mathrm{N}(\mathrm{CN})_{2}\right]$ presented a small increase of the $\mathrm{T}_{\text {onset }}$ to values close to 226 ${ }^{\circ} \mathrm{C}$. This IL-stabilizing effect was also previously verified by our group for chitosan-SPEs incorporating cyano-based ILs [39]. On the other side, regarding d$\operatorname{PCL}(530) /$ siloxane $_{n}\left[\mathrm{C}_{2} \mathrm{mim}\right][\mathrm{SCN}]$ ormolytes, the presence of $\left[\mathrm{C}_{2} \mathrm{mim}\right][\mathrm{SCN}]$ had a non-stabilizing 
effect on the host polymer matrix. The thermal degradation of the d$\operatorname{PCL}(530) /$ siloxane $_{n}\left[\mathrm{C}_{2} \mathrm{mim}\right][\mathrm{SCN}]$ samples is related to the IL thermal degradation. Figure 5e demonstrates that the $T_{\text {onset }}$ decreases with the increase of the quantity of added IL. The d$\operatorname{PCL}(530) /$ siloxane matrix initiates its thermal degradation at approximately $350{ }^{\circ} \mathrm{C}$, whereas in the case of the most IL concentrated sample d-PCL(530)/siloxane ${ }_{0.5}\left[\mathrm{C}_{2} \mathrm{mim}\right][\mathrm{SCN}]$ thermal decomposition initiates at $230{ }^{\circ} \mathrm{C}$. Similar results were found for d-PCL(530)/siloxane doped with different guest salts $[26,40]$.

From a thermal degradation step-wise analysis, the PCL-SPEs showed a stability higher than the gelatin-SPEs. Nevertheless, all SPEs presented $\mathrm{T}_{\text {onset }}$ values adequate for ECDs application.

\subsection{Morphology and structure}

The predominantly amorphous morphology is confirmed by the XRD diffractograms throughout the Gaussian shaped broad bands (Figure 6). The gelatin-SPEs $2 \theta=20.5-22^{\circ}$ peak is also characteristic of other systems based on gelatin [27, 33, 34] and other natural macromolecules $[25,28-30,41]$, while the d-PCL(530)/siloxane-SPEs $2 \theta=20.5-21^{\circ}$ peak is associated with the ordering of siliceous domains [3, 40, 42].

SEM images of gelatin ${ }_{x}[\mathrm{IL}]$ (Figure 7) and d-PCL(530)/ siloxane $_{n}\left[\mathrm{C}_{2} \mathrm{mim}\right][\mathrm{SCN}]$ (Figure 8) electrolytes show surface homogeneity with no obvious phase separation.

The light lines in figure $7 \mathrm{a}$ are probably replicas of the dish surface irregularities in which the samples solutions were poured. The gelatin ${ }_{2}\left[\mathrm{C}_{2} \mathrm{mim}\right]\left[\mathrm{N}(\mathrm{CN})_{2}\right]$ membrane seams to show a fibrous structure (Figure $7 \mathrm{~b}$ ). The micro-vesicle in figure $7 \mathrm{f}$ are probably clusters of glycerol [25].

The SEM images reproduced in figure 8 demonstrate that the d-PCL(530)/siloxane-samples exhibit an irregular texture. The texture of the d-PCL(530)/siloxane $5\left[\mathrm{C}_{2} \mathrm{mim}\right][\mathrm{SCN}]$ ormolyte (Figure 8b) exhibited micro-objects, some of them shapeless. The sample displayed a texture characteristic of the presence of crystalline regions.

The EDS analysis confirmed the presence of sulfur in the d- 
$\operatorname{PCL}(530) /$ siloxane $_{n}\left[\mathrm{C}_{2} \mathrm{mim}\right][\mathrm{SCN}]$ ormolytes. The results were obtained from the data average from five different places on each sample. This indicates the successful uniform incorporation of the IL. Similar results were found for chitosan-ILs-SPEs [25].

The $2 \mathrm{D}$ and $3 \mathrm{D}$ AFM images of gelatin ${ }_{1}\left[\mathrm{C}_{2} \mathrm{mim}\right][\mathrm{SCN}]$ and $\mathrm{d}-$ $\mathrm{CL}(530) /$ siloxane $_{10}\left[\mathrm{C}_{2} \mathrm{mim}\right][\mathrm{SCN}]$ SPEs are depicted in Figure 9. The images were acquired with a scanning area of $5.0 \mu \mathrm{m} \times 5.0 \mu \mathrm{m}$. Surface roughness analysis revealed that the two samples have very similar roughness mean square $(\mathrm{RMS})$ values, i.e., gelatin ${ }_{1}\left[\mathrm{C}_{2} \mathrm{mim}\right][\mathrm{SCN}] \mathrm{RMS}=8.50 \mathrm{~nm}$ and $\operatorname{PCL}(530) /$ siloxane $_{10}\left[\mathrm{C}_{2} \mathrm{mim}\right][\mathrm{SCN}] \mathrm{RMS}=8.92 \mathrm{~nm}$. The surface roughness of the gelatin-based samples ranged from 6.23 to $47.1 \mathrm{~nm}$. For the PCL-based ormolytes the RMS values varied between 2.13 and $259 \mathrm{~nm}$. The addition of ILs had a contradictory effect on the samples surface roughness. The sample with the highest RMS value, on the gelatin-based system, was gelatin matrix, which suggests that the ILs incorporated well on the gelatin polymer host. The dPCL(530)/siloxane matrix showed the lowest RMS value among the studied ormolytes. The dPCL(530)/siloxane ${ }_{n}[$ IL] SPEs high roughness might be explained by the crystalline domains observed in SEM images. Due to technical constrains, it was not possible to perform AFM analysis on the gelatin ${ }_{0.5}\left[\mathrm{C}_{2} \mathrm{mim}\right]\left[\mathrm{N}(\mathrm{CN})_{2}\right]$, d-PCL $(530)_{1}\left[\mathrm{C}_{2} \mathrm{mim}\right][\mathrm{SCN}]$, and $\mathrm{d}-\mathrm{PCL}(530)_{5}\left[\mathrm{C}_{2} \mathrm{mim}\right][\mathrm{SCN}]$ samples.

\subsection{ECD prototype characterization}

Prototype ECDs, with the configuration represented in figure 1, were assemble with $\operatorname{gelatin}_{0.5}\left[\mathrm{C}_{2} \mathrm{mim}\right]\left[\mathrm{N}(\mathrm{CN})_{2}\right]$, gelatin ${ }_{1}\left[\mathrm{C}_{2} \mathrm{mim}\right][\mathrm{SCN}]$, and $\mathrm{d}-\mathrm{PCL}(530) /$ siloxane $_{1}\left[\mathrm{C}_{2} \mathrm{mim}\right][\mathrm{SCN}]$ as electrolytes. The samples with higher ionic conductivity were chosen for the tests. Although all three SPEs were used to assemble ECDs, only the ECD with gelatin ${ }_{1}\left[\mathrm{C}_{2} \mathrm{mim}\right][\mathrm{SCN}]$ performed well. The successful characterization of the ECD with glass $/ \mathrm{ITO} / \mathrm{WO}_{3} /$ gelatin $_{1}\left[\mathrm{C}_{2} \mathrm{mim}\right][\mathrm{SCN}] / \mathrm{CeO}_{2}-\mathrm{TiO}_{2} / \mathrm{ITO} /$ glass configuration is presented here. 
Figure 10 depicts cyclic voltammograms of the tested ECD that was recorded at scan rates ranging from 50 to $500 \mathrm{mV} \cdot \mathrm{s}^{-1}$ and over the -2.8 to $3.0 \mathrm{~V}$ potential range. All voltammograms show a cathodic peak centered at $-2.1 \mathrm{~V}\left(50 \mathrm{mV} \cdot \mathrm{s}^{-1}\right)$, which corresponds to the reduction of the $\mathrm{WO}_{3}$ layer (coloration). The anodic peak is centered at $0.0 \mathrm{~V}\left(50 \mathrm{mV} \cdot \mathrm{s}^{-1}\right)$ and corresponds to the oxidation reaction (bleaching). The increase of the scan rate promotes an increase of the cathodic current from -0.40 to $-1.12 \mathrm{mAcm}^{-2}$ and its shift to more negative potentials. The anodic current peak also increases with increase of scan rate and shifts to more positive potentials ( 0.0 to $0.6 \mathrm{~V})$. The inset in Figure 10 plots the anodic and cathodic peaks currents against the square root of the scan rate. The plot linearity indicates that the mass transfer at the electrode surface is diffusion controlled [43].

The reversibility and stability of the ECD was tested by chronoamperometry cycling. Figure 11 shows the charge density response of the ECD for the $10^{\text {th }}$ and $640^{\text {th }}$ cycles. The change of color, from transparent to light blue, occurred by charging/discharging the electrochemical cell through the application of a potential of -2.8 and $3.0 \mathrm{~V}$ during $15 \mathrm{~s}$, respectively. The charge density decreased from $-17.53 \mathrm{mC}^{\cdot} \mathrm{cm}^{-2}$ at the $10^{\text {th }}$ cycle to $-2.71 \mathrm{mC}^{\cdot} \mathrm{cm}^{-2}$ at the $640^{\text {th }}$ cycle. For the initial sweeps, this value is more than twice the one reported for a gelatin-IL based electrolyte, -8.0 $\mathrm{mC}^{\circ} \mathrm{cm}^{-2}$ at $2.5 \mathrm{~V}$ [27], and for a gelatin- $\mathrm{LiClO}_{4} \mathrm{SPE},-8.0 \mathrm{mC} \mathrm{cm}^{-2}$ at $2.0 \mathrm{~V}$ [44]. The difference is even more pronounced for ECD with electrolytes based on other natural polymers such as DNA $[43,45,46]$, agar [30, 46], chitosan [47], gellan gum [48], or cellulose [49].

The decrease of the ECD performance is possibly related to the incomplete extraction of the inserted charge, which probably leads to the decrease of the device reversibility. The charge decrease on cycling might be related to the degradation of the interfacial contact between the electrolyte and the conducting materials, which is attributed to the volumetric change caused by the expansion and shrinkage of the active materials. This could lead to an increase in the charge transfer resistance. Additionally, due to the formation of passive films of ions of ILs during charge/discharge cycles, the activation of these ions decreased as the cycle test was repeated. Another explanation for this decrease of the reversibility can be due to the non-perfect nanoporous structure of the $\mathrm{WO}_{3}$ and 
$\mathrm{CeO}_{2}-\mathrm{TiO}_{2}$ thin films, where the charges accommodate during the insertion and extraction processes.

The transmission spectra obtained in the wavelength range between 190 and $1100 \mathrm{~nm}$ at the $10^{\text {th }}$ cycle for the as-deposited, colored, and bleached states are reproduced in Figure 12. The transmittance of the gelatin ${ }_{1}\left[\mathrm{C}_{2} \mathrm{mim}\right][\mathrm{SCN}]$-based $\mathrm{ECD}$ in the VIS region is identical to the asdeposited and bleached states. The maximum transmittance difference $\left(\Delta \mathrm{T}=\mathrm{T}_{\text {bleached }}-\mathrm{T}_{\text {colored }}\right)$ was $5.1 \%$ at $633 \mathrm{~nm}$. At $550 \mathrm{~nm}$ that difference was $4.6 \%$ (Figure 10). Under abundant illumination (daylight), the eye sensitivity is maximum at $550 \mathrm{~nm}$ [40]. At $640^{\text {th }}$ cycle, $\Delta \mathrm{T}=0.6 \%$ for both wavelengths. Thus, the optical density $\left(\mathrm{OD}=-\log \left(\mathrm{T}_{\text {colored }} / \mathrm{T}_{\text {bleached }}\right)\right)$ at $633 \mathrm{~nm}$ is 0.0690 and 0.0345 for $10^{\text {th }}$ and $640^{\text {th }}$ cycles, respectively. At $550 \mathrm{~nm}$, OD is 0.0562 and 0.0297 for $10^{\text {th }}$ and $640^{\text {th }}$ cycles, respectively.

The coloration efficiency (CE) of an ECD is defined as the change in optical density, at a defined wavelength, per unit of inserted charge [1]. Thus, for the $10^{\text {th }}$ cycle the CE is 3.94 and 3.21 $\mathrm{cm}^{2} \cdot \mathrm{C}^{-1}$ at 633 and $550 \mathrm{~nm}$, respectively.

Figure 13 demonstrates that the tested ECD has a good open circuit memory of approximately 4 hours.

\section{Conclusions}

Gelatin and d-PCL(530)/siloxane electrolytes doped with cyano-based ILs were prepared through solvent casting and sol-gel methods, respectively. The ionic conductivity, thermal behavior, morphology, and structure of the samples encouraged us to incorporate these materials as electrolytes in ECDs. The features that made these materials interesting for application in ECDs include adequate ionic conductivity $\left(\sim 10^{-3}\right.$ and $\left.10^{-5} \mathrm{Scm}^{-1}\right)$ and high thermal stability $\left(\mathrm{T}_{\text {onset }}>170\right.$ $\left.{ }^{\circ} \mathrm{C}\right)$. Also, except the d-PCL(530)/siloxane matrix, all the SPEs exhibited an amorphous morphology. Gelatin ${ }_{x}[\mathrm{IL}]$ ionic conductivity decreased in the order: gelatin ${ }_{\mathrm{x}}\left[\mathrm{C}_{2} \mathrm{mim}\right]\left[\mathrm{N}(\mathrm{CN})_{2}\right]>$ $\operatorname{gelatin}_{\mathrm{x}}\left[\mathrm{C}_{2} \operatorname{mim}\right][\mathrm{SCN}]>\operatorname{gelatin}_{\mathrm{x}}\left[\mathrm{C}_{2} \mathrm{mim}\right]\left[\mathrm{C}(\mathrm{CN})_{3}\right]>$ gelatin $_{\mathrm{x}}\left[\mathrm{C}_{4} \mathrm{mim}\right][\mathrm{SCN}]$. Ionic conductivity 
increased with the increase of the quantity of added IL. The quantity of IL also influenced the d$\operatorname{PCL}(530) /$ siloxane $_{n}\left[\mathrm{C}_{2} \mathrm{mim}\right][\mathrm{SCN}]$ ormolytes thermal stability. It decreased with the increase of the quantity of IL present in the membrane.

Although ionic conductivity is the most relevant feature for ECD application, the characterization of a prototype ECD was not successful using gelatin ${ }_{0.5}\left[\mathrm{C}_{2} \mathrm{mim}\right]\left[\mathrm{N}(\mathrm{CN})_{2}\right]$. This membrane displayed the highest ionic conductivity values $\left(2.40 \times 10^{-3}\right.$ and $1.68 \times 10^{-2} \mathrm{Scm}^{-1}$ at 25 and $95{ }^{\circ} \mathrm{C}$, respectively). Nevertheless, the gelatin ${ }_{1}\left[\mathrm{C}_{2} \mathrm{mim}\right][\mathrm{SCN}] \mathrm{SPE}$ ionic conductivity values of $5.50 \times 10^{-5}$ and $3.98 \times 10^{-3} \mathrm{Scm}^{-1}$ at 25 and $95^{\circ} \mathrm{C}$, respectively were still very high and adequate for the application of this sample as electrolyte in an ECD.

An ECD with the configuration glass/ITO/ $/ \mathrm{WO}_{3} /$ gelatin $_{1}\left[\mathrm{C}_{2} \mathrm{mim}\right][\mathrm{SCN}] / \mathrm{CeO}_{2}$ $\mathrm{TiO}_{2} / \mathrm{ITO} /$ glass was assembled and electrochemically and spectroscopically characterized. The promising results confirmed the applicability of this class of materials in commercial devices. For the $10^{\text {th }}$ cycle and at $633 \mathrm{~nm}$, the prototype ECD showed an $\Delta \mathrm{T}=5.1 \%, \mathrm{OD}=0.0690$, and $\mathrm{CE}=$ $3.94 \mathrm{~cm}^{2} \mathrm{C}^{-1}$. Color switching time was very fast $(\sim 15 \mathrm{~s})$ and optical memory persisted for approximately 4 hours. Although some optimization work is required, these results are encouraging.

\section{Acknowledgments}

This work was supported by Fundação para a Ciência e a Tecnologia (FCT) in the framework of the Research unit GREEN-it "Bioresources for Sustainability" (UID/Multi/04551/2013), Laboratório Associado para a Química Verde - Tecnologias e Processos Limpos-LAQV (UID/QUI/50006/2013), grant SRFH/BD/90366/2012 (R.L.) and a contract under Investigador FCT 2012 program (J.M.S.S.E.). It was also co-financed by FEDER through the COMPETE Program and PT2020 Partnership Agreement (POCI-01-0145-FEDER - 007265). M.M. Silva acknowledges CNPq (PVE grant 406617/2013-9) for the mobility grant provided by this institution. A. Pawlicka and R.C. Sabadini acknowledge CNPq (grant 305029/2013-4 and 152252/2016-9), and F.C. Sentanin acknowledges CAPES (grant PNPD20131739- 
33002045017P6).

\section{References}

[1] V.K. Thakur, G. Ding, J. Ma, P.S. Lee, X. Lu, Hybrid materials and polymer electrolytes for electrochromic device applications, Adv. Mater. 24 (2012) 4071-4096.

[2] M.M. Silva, P.C. Barbosa, L.C. Rodrigues, A. Gonçalves, C. Costa, E. Fortunato, Gelatin in electrochromic devices, Opt. Mater. 32 (2010) 719-722.

[3] M. Fernandes, R. Leones, A.M.S. Costa, M.M. Silva, S. Pereira, J.F. Mano, E. Fortunato, R. Rego, V. de Zea Bermudez, Electrochromic devices incorporating biohybrid electrolytes doped with a lithium salt, an ionic liquido or a mixture of both, Electrochim. Acta 161 (2015) 226-235.

[4] NTERA, https://www.linkedin.com/company/ntera (accessed 07.10.2016).

[5] GENTEX Corporation, http://www.gentex.com/ (accessed 07.10.2016).

[6] PR Newswire, http://www.prnewswire.co.uk/news-releases/donnelly-corporation-producingelectrochromic-mirrors-for-audi-vehicles-156272505.html (accessed 07.10.16).

[7] P. Barbosa, L.C. Rodrigues, M.M. Silva, M. Smith, A. Goncalves, E. Fortunato, Application of di-ureasil ormolytes based on lithium tetrafluoroborate in solid-state electrochromic displays, J. Mater. Chem. 20 (2010) 723-730.

[8] K.R. Jeffrey, G.Z. Zukowska, J.R. Stevens, Dynamics of the hydrogen and phosphate ions in proton conducting gel/ $\mathrm{D}_{3} \mathrm{PO}_{4}$ electrolytes: a ${ }^{2} \mathrm{H}$ and ${ }^{31} \mathrm{P}$ nuclear magnetic resonance study, J. Chem. Phys. 119 (2003) 2422-2431.

[9] D.R. Rosseinsky, R.J. Mortimer, Electrochromic systems and the prospects for devices, Adv. Mater. 13 (2001) 783-793.

[10] A.A. Karim, R. Bhat, Fish gelatin: properties, challenges, and prospects as an alternative to mammalian gelatins, Food Hydrocolloid. 23 (2009) 563-576.

[11] T.R. Keenan, Gelatin in A.J. Domb, J. Kost, D.M. Wiseman (Eds.), Handbook of biodegradable polymers, Hardwood Academic Publishers, Amsterdam, 1997, pp. 307-317. 
[12] W. Lu, A.G. Fadeev, B. Qi, E. Smela, B.R. Mattes, J. Ding, G.M. Spinks, J. Mazurkiewicz, D. Zhou, G.G. Wallace, D.R. MacFarlane, S.A. Forsyth, M. Forsyth, Use of Ionic Liquids for $\pi$ Conjugated Polymer Electrochemical Devices, Science 297 (2002) 983-987.

[13] M.J. Earle, J.M.S.S. Esperança, M.A. Gilea, J.N. Canongia Lopes, L.P.N. Rebelo, J.W. Magee, K.R. Seddon, J.A. Widegren, The distillation and volatility of ionic liquids, Nature 439 (2006) 831834.

[14] M. Smiglak, W.M. Reichert, J.D. Holbrey, J.S. Wilkes, L.Y. Sun, J.S. Thrasher, K. Kirichenko, S. Singh, A.R. Katritzky, R.D. Rogers, Combustible ionic liquids by design: Is laboratory safety another ionic liquid myth? Chem. Commun. 24 (2006) 2554-2556.

[15] K.J. Baranyai, G.B. Deacon, D.R. MacFarlane, J.M. Pringle, J.L. Scott, Thermal degradation of ionic liquids at elevated temperatures, Aust. J. Chem. 57 (2004) 145-147.

[16] J.F.D. Holbrey, K.R. Seddon, Ionic liquids, Clean Prod. Processes 1 (1999) 223-236.

[17] N.V. Plechkova, K.R. Seddon, Applications of ionic liquids in the chemical industry, Chem. Soc. Rev. 37 (2008) 123-150.

[18] S. Zhang, X. Lu, Q. Zhou, X. Li, X. Zhang, S. Li, Ionic Liquids Physicochemical Properties, Elsevier, Oxford, 2009.

[19] E.H. Cha, S.A. Lim, J.H. Park, D.W. Kim, D.R. Macfarlane, Ionic conductivity studies of gel polyelectrolyte based on ionic liquid, J. Power Sources 178 (2008) 779-782.

[20] G. Sun, K. Li, C. Sun, Application of 1-ethyl-3-methylimidazolium thiocyanate to the electrolyte of electrochemical double layer capacitors, J. Power Sources 162 (2006) 1444-1450.

[21] D. Weingarth, I. Czekaj, Z. Fei, A. Foelske-Schmitz, P.J. Dyson, A. Wokaun, R. Kötz, Electrochemical stability of imidazolium based ionic liquids containing cyano groups in the anion: a cyclic voltammetry, XPS and DFT study, J. Electrochem. Soc. 159 (2012) H611-H615.

[22] S.C. Nunes, V. de Zea Bermudez, M.M. Silva, M.J. Smith, E. Morales, L.D. Carlos, R.A.S. Ferreira, J. Rocha, Sol-gel derived $\mathrm{Li}^{+}$-doped poly(ع-caprolactone)/siloxane biohybrid electrolytes, J. Solid State Electrochem. 10 (2006) 203-210. 
[23] R. Azimirad, O. Akhavan, A. Z. Moshfegh, Influence of coloring voltage and thickness on electrochromical properties of e-beam evaporated $\mathrm{WO}_{3}$ thin films, J. Electrochem. Soc. 153 (2006) E11-E16.

[24] F.M. Gray, Solid Polymer Electrolytes: Fundamentals and Technological Applications; VCH Publishers Inc., New York, 1991.

[25] R. Leones, F. Sentanin, S.C. Nunes, J.M.S.S. Esperança, M.C. Gonçalves, A. Pawlicka, V. de Zea Bermudez, M.M. Silva, Effect of the alkyl chain length of the ionic liquid anion on polymer electrolytes properties, Electrochim. Acta 184 (2015) 171-178.

[26] L.C. Rodrigues, M.M. Silva, M.J. Smith, A. Gonçalves, E. Fortunato, Poly(عcaprolactone)/siloxane biohybrids with application in "smart windows", Synthetic Met. 161 (2012) 2682-2687.

[27] R. Leones, F. Sentanin, L.C. Rodrigues, R.A.S. Ferreira, I.M. Marrucho, J.M.S.S. Esperança, A. Pawlicka, L.D. Carlos, M.M. Silva, Novel polymer electrolytes based on gelatin and ionic liquids, Opt. Mat. 36 (2012) 187-195.

[28] R. Leones, L.C. Rodrigues, A. Pawlicka, J.M.S.S. Esperança, M.M. Silva, Characterization of flexible DNA films, Electrochem. Comm. 22 (2012) 189-192.

[29] R. Leones, J.M.S.S. Esperança, A. Pawlicka, V. de Zea Bermudez, M.M. Silva, Polymer electrolyte based on DNA and N,N,N-trimethyl-N-(2-hydroxyethyl)ammonium bis(trifluoromethylsulfonyl)imide, J. Electroanal. Chem. 748 (2015) 70-75.

[30] R. Leones, F. Sentanin, L.C. Rodrigues, I.M. Marrucho, J.M.S.S. Esperança, A. Pawlicka, M.M. Silva, Investigation of polymer electrolytes based on agar and ionic liquids, Express Polym. Lett. 6 (2012) 1007-1016.

[31] Q. Li, H. Ardebili, Flexible thin-battery based on solid-like ionic liquid-polymer electrolyte, J. Power Sources 303 (2013) 17-21.

[32] R. Leones, C.M. Costa, A.V. Machado, J.M.S.S. Esperança, M.M. Silva, S. Lanceros-Mendez, Effect of ionic liquid anion type in the performance of solid polymer electrolytes based on 
poly(vinylidene fluoride-trifluoroethylene), Electroanal. 27 (2015) 457-464.

[33] D.F. Vieira, C.O. Avellaneda, A. Pawlicka, Conductivity study of a gelatin-based polymer electrolyte, Electrochim. Acta 53 (2007) 1404-1408.

[34] C.O. Avellaneda, D.F. Vieira, A. Al-Kahlout, E.R. Leite, A. Pawlicka, M.A. Aegerter, Solidstate electrochromic devices with $\mathrm{Nb}_{2} \mathrm{O}_{5}$ : Mo thin film and gelatin-based electrolyte, Electrochim. Acta 53 (2007) 1648-1654.

[35] D.R. MacFarlane, J. Golding, S. Forsyth, M. Forsyth, G.B. Deacon, Low viscosity ionic liquids based on organic salts of the dicyanamide anion, Chem. Commun. 16 (2001) 1430-1431.

[36] Deng, M.-J.; Chen, P.-Y.; Leong, T.-I.; Sun, I.-W.; Chang, J.-K.; Tsai, W.-T. Dicyanamide anion based ionic liquids for electrodeposition of metals, Electrochem. Commun. 10 (2008) 213-216.

[37] Q. Zhang, M. Li, X. Zhang, X. Wu, The thermodynamic estimation and viscosity, electrical conductivity characteristics of 1-alkyl-3-methyl-imidazolium thiocyanate ionic liquids, Z Phys. Chem. 228 (2014) 851-867.

[38] M.J. Smith, C.J. Silva, M.M. Silva, The study of a lanthanum triflate based polymer electrolyte using electrochemical and thermal techniques, Solid State Ionics 60 (1993) 73-78.

[39] R. Leones, R.C. Sabadini, J.M.S.S. Esperança, A. Pawlicka, M.M. Silva, Effect of storage time on the ionic conductivity of chitosan-solid polymer electrolytes incorporating cyano-based ionic liquids, submitted to Electrochim. Acta.

[40] M. Fernandes, S.S. Nobre, L.C. Rodrigues, A. Gonçalves, R. Rego, M.C. Oliveira, R.A.S. Ferreira, E. Fortunato, M.M. Silva, L.D. Carlos, V. de Zea Bermudez, $\mathrm{Li}^{+}-$and $\mathrm{Eu}^{3+}$-doped poly( $(\varepsilon-$ caprolactone)/siloxane biohybrid electrolytes for electrochromic devices, ACS Appl. Mater. Interfaces 3 (2011) 2953-2965.

[41] E. Raphael, C.O. Avellaneda, B. Manzolli, A. Pawlicka, Agar-based films for application as polymer electrolytes, Electrochim. Acta 55 (2010) 1455-1459.

[42] R.F.P. Pereira, J.P Donoso, C.J. Magon, I.D.A. Silva, M.A. Cardoso, M.C. Gonçalves, R.C. Sabadini, A. Pawlicka, V. de Zea Bermudez, M.M. Silva, Ion conducting and paramagnetic d- 
PCL(530)/siloxane-based biohybrids doped with $\mathrm{Mn}^{2+}$ ions, Electrochim. Acta, 211 (2016) 804813.

[43] A. Pawlicka, F. Sentanin, A. Firmino, J.G. Grote, F. Kajzar, I. Rau, Ionically conducting DNAbased membranes for electrochromic devices, Synthetic Met. 161 (2011) 2329-2334.

[44] C.O. Avellaneda, D.F. Vieira, A. Al-Kahlout, S. Heusing, E.R. Leite, A. Pawlicka, M.A. Aergerter, All solid-state electrochromic devices with gelatin-based electrolyte, Sol. Energy Mater. Sol. Cells 92 (2008) 228-233.

[45] R. Leones, M. Fernandes, F. Sentanin, I. Cesarino, J.F. Lima, V. de Zea Bermudez, A. Pawlicka, C.J. Magon, J.P. Donoso, M.M. Silva, Ionically conducting $\mathrm{Er}^{3+}$-doped DNA-based biomembranes for electrochromic devices, Electrochim. Acta 120 (2014) 327-333.

[46] L.M.N. Assis, R. Leones, J. Kanicki, A. Pawlicka, M.M. Silva, Prussian blue for electrochromic devices, J. Electroanal. Chem. 777 (2016) 33-39.

[47] R. Alves, F. Sentanin, R.C. Sabadini, A. Pawlicka, M.M. Silva, Influence of cerium triflate and glycerol on electrochemical performance of chitosan electrolytes for electrochromic devices, Electrochim. Acta 217 (2016) 108-116.

[48] M.J. Neto, F. Sentanin, J.M.S.S. Esperança, M.J. Medeiros, A. Pawlicka, V. de Zea Bermudez, M.M. Silva, Gellan gum-ionic liquid membranes for electrochromic device application, Solid State Ionics 274 (2015) 64-70.

[49] P. Ledwon, J.R. Andrade, M. Lapkowski, A. Pawlicka, Hydroxypropyl cellulose-based gel electrolyte for electrochromic devices, Electrochim. Acta 159 (2015) 227-233. 


\section{Figures caption}

Figure 1. Representation of an ECD with glass/ITO/ $\mathrm{WO}_{3} / \mathrm{SPE} / \mathrm{CeO}_{2}-\mathrm{TiO}_{2} / \mathrm{ITO} /$ glass configuration.

Figure 2. Variation of the $\log$ ionic conductivity with the inverse temperature of the (a) gelatin $_{\mathrm{x}}\left[\mathrm{C}_{2} \operatorname{mim}\right]\left[\mathrm{C}(\mathrm{CN})_{3}\right], \quad$ (b) gelatin $_{\mathrm{x}}\left[\mathrm{C}_{2} \mathrm{mim}\right]\left[\mathrm{N}(\mathrm{CN})_{2}\right], \quad$ (c) gelatin ${ }_{\mathrm{x}}\left[\mathrm{C}_{2} \mathrm{mim}\right][\mathrm{SCN}]$ and gelatin $_{x}\left[\mathrm{C}_{4} \operatorname{mim}\right][\mathrm{SCN}]$, and (d) d-PCL(530)/siloxane ${ }_{n}\left[\mathrm{C}_{2}\right.$ mim $][\mathrm{SCN}]$ SPEs.

Figure 3. Isotherms of the log ionic conductivity vs composition of the gelatin ${ }_{x}[\mathrm{IL}]$ SPEs, at approximately $30^{\circ} \mathrm{C}$.

Figure 4. DSC thermograms of SPEs based on (a) gelatin between -60 and $200{ }^{\circ} \mathrm{C}$, (b) dPCL(530)/siloxane between 60 e $15{ }^{\circ} \mathrm{C}$, and (c) between 25 and $350{ }^{\circ} \mathrm{C}$.

Figure 5. TGA curves of the (a) gelatin ${ }_{x}\left[\mathrm{C}_{2} \mathrm{mim}\right]\left[\mathrm{C}(\mathrm{CN})_{3}\right]$, (b) gelatin ${ }_{\mathrm{x}}\left[\mathrm{C}_{2} \operatorname{mim}\right]\left[\mathrm{N}(\mathrm{CN})_{3}\right]$,

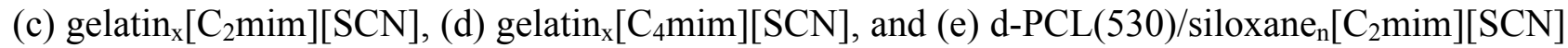
electrolytes.

Figure 6. X-ray diffraction patterns of (a) gelatin-SPEs incorporating (a1) $\left[\mathrm{C}_{2} \mathrm{mim}\right][\mathrm{SCN}]$, (a2) $\left[\mathrm{C}_{4} \mathrm{mim}\right][\mathrm{SCN}],(\mathrm{a} 3)\left[\mathrm{C}_{2} \mathrm{mim}\right]\left[\mathrm{N}(\mathrm{CN})_{2}\right]$, and (a4) $\left[\mathrm{C}_{2} \mathrm{mim}\right]\left[\mathrm{C}(\mathrm{CN})_{3}\right]$, with $(.1) \mathrm{n}=4,(.2) \mathrm{n}=2$, (.3) $\mathrm{n}=1$, and (.4) $\mathrm{n}=0.5$; and (b) d-PCL(530)/siloxane $\mathrm{n}_{\mathrm{n}}\left[\mathrm{C}_{2} \mathrm{mim}\right][\mathrm{SCN}]-\mathrm{SPEs}$ with (b1.1) $\mathrm{n}=50$, (b1.2) $n=25,(b 1.3) n=10,(b 1.4) n=5$, and (b1.5) $n=1$.

Figure 7. SEM pictures of the (a) gelatin $2\left[\mathrm{C}_{2} \operatorname{mim}\right]\left[\mathrm{C}(\mathrm{CN})_{3}\right]$, (b) gelatin $2\left[\mathrm{C}_{2} \operatorname{mim}\right]\left[\mathrm{N}(\mathrm{CN})_{2}\right]$, (c) $\operatorname{gelatin}_{0.5}\left[\mathrm{C}_{2} \operatorname{mim}\right]\left[\mathrm{N}(\mathrm{CN})_{2}\right]$, (d) $\operatorname{gelatin}_{2}\left[\mathrm{C}_{2} \mathrm{mim}\right][\mathrm{SCN}]$, (e) gelatin $2\left[\mathrm{C}_{4} \operatorname{mim}\right][\mathrm{SCN}]$, and (f) 
gelatin matrix membranes.

Figure 8. SEM pictures of the d-PCL(530)/siloxane ${ }_{n}\left[C_{2}\right.$ mim $][S C N]$ ormolytes, with (a) $n=$ 1, (b) $n=5$, (c) $n=10$, (d) $n=25$, (e) $n=50$, and (f) d-PCL(530)/siloxane matrix.

Figure 9. AFM images of the (a) gelatin ${ }_{1}\left[\mathrm{C}_{2} \operatorname{mim}\right][\mathrm{SCN}]$ and (b) d$\operatorname{PCL}(530) /$ siloxane $_{10}\left[\mathrm{C}_{2} \mathrm{mim}\right][\mathrm{SCN}]$ electrolytes.

Figure 10. Cyclic voltammograms between -2.8 and $3.0 \mathrm{~V}$ at different scan rates. The inset depicts the anodic and cathodic peaks current densities against the square root of the scan rates of ECD with glass/ITO/ $\mathrm{WO}_{3} /$ gelatin $1\left[\mathrm{C}_{2} \mathrm{mim}\right][\mathrm{SCN}] / \mathrm{CeO}_{2}-\mathrm{TiO}_{2} / \mathrm{ITO} /$ glass configuration.

Figure 11. Charge density results of the $10^{\text {th }}$ and $640^{\text {th }}$ cycles of ECD with glass/ITO/ $\mathrm{WO}_{3} /$ gelatin 1 [ $\left.\mathrm{C}_{2} \mathrm{mim}\right][\mathrm{SCN}] / \mathrm{CeO}_{2}-\mathrm{TiO}_{2} / \mathrm{ITO} /$ glass configuration.

Figure 12. Transmission spectra for the as-deposited, bleached, and colored states of ECD with glass $/ \mathrm{ITO} / \mathrm{WO}_{3} /$ gelatin $1\left[\mathrm{C}_{2} \mathrm{mim}\right][\mathrm{SCN}] / \mathrm{CeO}_{2}-\mathrm{TiO}_{2} / \mathrm{ITO} /$ glass configuration at the $10^{\text {th }}$ cycle.

Figure 13. Memory test of ECD with glass/ITO/ $\mathrm{WO}_{3} /$ gelatin $_{1}\left[\mathrm{C}_{2} \mathrm{mim}\right][\mathrm{SCN}] / \mathrm{CeO}_{2}$ $\mathrm{TiO}_{2} / \mathrm{ITO} /$ glass configuration. 